\title{
Economic evaluation of biorational and conventional insecticides for the control of maize stem borer Chilo partellus (Swinhoe) in Zea mays
}

\section{Ravinder Kumar* and Jawala Jindal}

Maize section, Department of Plant Breeding and Genetics, Punjab Agricultural University, Ludhiana (Punjab), INDIA

*Corresponding author. Email: drravinderchandel@pau.edu

Received: February, 13, 2015; Revised received: July 11, 2015; Accepted: August 12, 2015

Abstract: Maize borer, Chilo partellus (Swinhoe) is the chief limiting factor for higher corn production. Field trials to assess the efficacy of different insecticides against $C$. partellus were carried in district Ropar, Punjab. It was observed that significantly lesser leaf injury incidence was recorded in biorational treatment $T_{1}$ : chlorantriniliprole 18.5 SC (3.43 \& 4.23) in comparison to broad spectrum conventional insecticide treatment $\mathrm{T}_{3}$ : Deltamethrin $2.8 \mathrm{EC}$ (4.63\& 5.36) and $T_{4}$ :Farmer's practice 4.43 and 6.93. Whereas in plots with parasitoid application $\left(T_{2}\right)$, the leaf injury incidence was recorded to be 6.56 \& 7.86 during 2012 and 2013 , respectively. Though $T_{2}$ was statistically superior to control, however it was not at par with insecticide treatments. Furthermore similar trend was observed for deadhearts reduction in different treatments. It was recorded to be 3.16 and 3.90, 3.33 and 3.96, 3.53 and 3.96 in insecticide treatment plots $T_{1}, T_{3}$ and $T_{4}$ respectively. The economic returns on the basis of marketable grain yield in insecticide treated plots was more in $T_{1}$ followed by $T_{3}$ and $T_{4}(51.99,49.58$ and 48.51) in comparison to control (40.44) and biological control plots (46.75). Therefore experimental data revealed overall superiority of biorational pesticide in comparison to conventional insecticides for reduction in pest damage and economic returns. Hence the option of biorational for the control of maize stem borer not only justify safety to environment but also offers effective control of borer population in maize ecosystem due to its distinct chemical class and unique mode of action.

Keywords: Biorational, Chilo partellus, Chlorantriniliprole, Maize borer, Trichogramma

\section{INTRODUCTION}

The maize crop yield in India lags behind leading corn producing countries of the world in terms of productivity. Insects hitherto unknown to attack the maize crop now inflicts significant losses. At present total losses inflicted by different insect pests and diseases at different growth stages of the crop has been estimated in the order of $13.2 \%$ under varied climatic conditions in India (Kumar et al, 2014 ) The maize stem borer, Chilo partellus (Swinhoe) is a key pest and reported to cause 7.0-35.7 per cent loss in grain yield in different agro-climatic regions of India (Anonymous, 2013). For its sound management strategy, effective chemicals and their timing of application (early whorl stage) is significant as this pest is internal feeder and control at later stage offers narrow scope for chemical control, In recent years as a part of pest management strategy, various methods of pest control have been developed to check the economic losses with more emphasis on new chemistry molecules, biological control and agronomic manipulations etc. The traditional insecticides like deltamethrin, fenvalerate, cypermehtrin, monocrotophos and carabryl etc. are in use over decades and to strengthen insecticide resistance management strategy, effective and environmentally safe insecticides with novel mode of actions should be focused. Chlorantraniliprole 18.5 SC is a new chemistry belonging to anthranilamide group having unique mode of action in muscle disruption and has been found effective against many lepidopteron insect pests (Hannig et al., 2009) and safer to beneficial organisms (Marchesini et al., 2008). Further the egg parasitoid Trichogramma chilonis Ishii has been found to be effective and economical at early whorl stage of the crop growth (Jalai and Singh 2003). This technology is also recommended in Punjab state by Punjab Agricultural University as a component of IPM strategy. Therefore, to demonstrate these promising tools of pest management at farmer's field and economic comparison of different insecticide treatments (biorational vs conventional) the present study was undertaken in the form of on-farm trials with the intent to demonstrate and validate the control efficacy of new insecticide treatment at farmer's field and also to provide a choice of effective as well as safer insecticide for the management of $C$. partellus for sustainable maize production.

\section{MATERIALS AND METHODS}

The present study about evaluation of different insecticides and their comparative economics, consisted four insecticide treatments including two biorational insecticides $\left(\mathrm{T}_{1}\right.$ and $\mathrm{T}_{2}$ ) and two conventional chemical insecticides 
$\left(\mathrm{T}_{3}\right.$ and $\left.\mathrm{T}_{4}\right)$. The various treatments thus encompasses $\mathrm{T}_{1}$ : Chlorantriniliprole 18.5 SC (@75 ml per hectare); $\mathrm{T}_{2}$ : biological control with Tricho cards (@ 100,000 Trichogramma chilonis parasitised eggs of Corycra cephalonica per hectare on 14 days old crop); $\mathrm{T}_{3}$ : Deltamethrin 2.8 EC @ $200 \mathrm{ml}$ sprayed on 14 days old crop as a standard check and $\mathrm{T}_{4}$ : Farmer's practice (Lara@ $250 \mathrm{ml}$, a mixture insecticide formulation with Chlorpyriphas 50\% + Cypermethrin 5\%) sprayed on crop at the appearance of dead hearts and $\mathrm{T}_{5}$ : untreated control. These studies were conducted in kharif seasons during 2012 and 2013 in the form of 5 (five) On-farm trails at farmer's field in five different blocks of district Ropar in Punjab. Thus in each location, an area of one acre was divided into five sub-plots $\left(800 \mathrm{~m}^{2}\right.$ each) representing five treatments each having three replicates within the sub-plot. The various treatments were applied to each sub plot at 14 days after germination except in plots with farmer's practice treatment $\left(\mathrm{T}_{4}\right)$. The observation were recorded at 7 and 14 days after spray as well as 0 day (before spray), At harvest the yield was recorded in each treatment plots and converted to hectare basis. The data on borer damage in the form of per cent incidence of leaf injury and dead hearts incidence was estimated by randomly examining 100 plants in each treatment plot at 3 sub sampling. The mean data of all the locations was pooled and statistical analysis was conducted with two way analysis of variance where means were separated by Least square difference LSD values. (Gomez \& Gomez, 1984) The comparative increase in grain yield and cost benefits ratio (increment grain yield and $\mathrm{B}: \mathrm{C}$ ratio) was calculated by subtracting market value of grain yield under different treatments - market value of grain yield in control taking into account the prevailing market price of produce, inputs and labour charges.

\section{RESULTS AND DISCUSSION}

Leaf injury incidence: The incidence of leaf injury due to natural infestation of $C$. partellus was recorded 14 days after spray in different treatment plots during the year 2012 and 13 as presented in Table1. The leaf injury in different treatments viz Biorational, $\mathrm{T}_{1}$ : (3.43 $\& 4.23)$ was significantly better $(\mathrm{p}=\mathbf{0} 0.05)$ in comparison to conventional insecticide $\mathrm{T}_{3}:(4.63 \& 5.36)$ and $\mathrm{T}_{4}:$ 4.43 and 6.93. However in $\mathrm{T}_{2}$ : the leaf injury incidence was 6.56 and 7.86 in 2012 and 2013 respectively and significantly superior $(\mathrm{p}=0.05)$ to $\mathrm{T}_{5}$ : control, but it was not at par with insecticide treated plots.

Dead hearts incidence: The incidence of dead hearts as presented in Table 2, recorded 14 days after spray during 2012 and 2013 was 3.16 and $3.90,3.33$ and 3.96, 3.53 and 3.96 in $\mathrm{T}_{1}, \mathrm{~T}_{2}$ and $\mathrm{T}_{3}$ respectively. The Bio-rational and chemical treatments performed equally promising for reduction in dead hearts but were statistically superior to control plots. The plots receiving parasitoid release $\left(\mathrm{T}_{2}\right)$ recorded 5.14 and 4.90 dead hearts incidence as compared with control 14.16 and 18.53. The overall means of all data parameters during both years as presented in Figure 1 and 2 recorded dead hearts incidence in the range of 3.72- 4.84 in different treatments over control (8.85) during the 2012 and 3.76-5.09 as compared with 14.74 in control during the year 2013.

Grain yield: The crop yield in the form of grain output in each treatment on plot basis and converted to hactare basis $(\mathrm{q} / \mathrm{ha})$ and presented in Table 3 revealed the similar pattern with higher yield in plots $\mathrm{T}_{1}(52.23$ and 51.76 $\mathrm{q} / \mathrm{ha})$ followed by $\mathrm{T}_{3}$ and $\mathrm{T}_{4}(50.50$ and $48.66 ; 49.70$ and $47.33 \mathrm{q} / \mathrm{ha}$ ) respectively during two years of study period. In plots with biological control treatment also yield was (47.40 and $46.10 \mathrm{q} / \mathrm{ha}$ ) significantly better $(p=0.05)$ than control $(40.73$ and $40.16 \mathrm{q} / \mathrm{ha})$ thus all the treatments indicated their superiority in better yield realization as compared with control.

Economic analysis : The untreated plots had statistically lower grain yield as compared with different treatments due to $C$. partellus infestation. Hence enhanced grain yield in range of 6.30-11.3 (Pooled mean of two years as shown in Table 3) was achieved by use of different protective measures in different treatments over the control. The mentioned biorational $\left(\mathrm{T}_{1}\right.$ and $\left.\mathrm{T}_{2}\right)$ as well as conventional insecticides $\left(\mathrm{T}_{3}\right.$ and $\left.\mathrm{T}_{4}\right)$ resulted in net profit of Rs. 7149-12223 per hectare during two years of study period. Thus chlorantraniliprole@ $75 \mathrm{ml} / \mathrm{ha}$ promises to be a strong new addition in maize pest management programme based on its properties of improved plant mobility and increased spectrum of insect control on Lepidopteran pests (Anuradha, 2013). In furtherance to superiority of biorational treatment $T_{1}$, the initial higher cost is compensated with better efficacy against pest over a longer period and realization of higher grain yield as compared with all other treatments under consideration (Figs.1 and 2) during the year 2012 and 2013.

Earlier workers also reported effectiveness of chlorantraniliprole in managing the lepidopteran borer in rice, sugarcane and brinjal (Wu-Jun et al., 2009; Singh et al., 2009; Suri, 2011 and Rajaval et al., 2011). Moreover, it was found safer to the beneficial insects in the maize and other agro ecosystems with additional benefit of environmentally sound approach as propounded by Marchesini et al. (2008). The biological control plots receiving single release of Trichogramma chilonis also recorded significant reduction in damage as compared with control but the per cent damage due to pest and monetary returns were not comparable with other biorational and chemical insecticides treatments. Farid et al (2007) reported that four releases of $T$. chilonis during the season led to as high as $68 \%$ decrease in damage over control indicating the success of sequential release and it is in confirmation with the findings of Aggarwal and Jindal (2013), advocating inundative releases of $T$. chilonis in Kharif season maize under Punjab conditions to achieve better control. The farmer's practice of using insecticide at 
Table 1. Effect of different treatments on reduction of leaf injury incidence of C. partellus in maize during Kharif 2012 and 2013.

\begin{tabular}{|c|c|c|c|c|c|c|c|}
\hline \multirow[b]{2}{*}{ Treatments } & \multirow[b]{2}{*}{$\begin{array}{l}\text { Dose (ml/ } \\
\text { ha) }\end{array}$} & \multicolumn{3}{|c|}{$\begin{array}{l}\text { Per cent leaf injury incidence } \\
(\mathbf{2 0 1 2})\end{array}$} & \multicolumn{3}{|c|}{$\begin{array}{l}\text { Per cent leaf injury incidence } \\
\text { (2013) }\end{array}$} \\
\hline & & $\begin{array}{l}\text { Before } \\
\text { Spray }\end{array}$ & $\begin{array}{c}7 \text { days after } \\
\text { spray }\end{array}$ & $\begin{array}{c}14 \text { days } \\
\text { after spray }\end{array}$ & $\begin{array}{l}\text { Before } \\
\text { Spray }\end{array}$ & $\begin{array}{c}7 \text { days } \\
\text { after } \\
\text { spray }\end{array}$ & $\begin{array}{c}\text { 14 days } \\
\text { after spray }\end{array}$ \\
\hline $\mathrm{T}_{1}$ & 75 & $\begin{array}{c}10.76 \\
(19.14)\end{array}$ & $\begin{array}{c}4.67 \\
(12.59)\end{array}$ & $\begin{array}{c}3.43 \\
(10.66)\end{array}$ & $\begin{array}{c}13.0 \\
(21.12)\end{array}$ & $\begin{array}{c}5.03 \\
(12.80)\end{array}$ & $\begin{array}{c}4.23 \\
(11.21)\end{array}$ \\
\hline $\mathrm{T}_{2}$ & $\begin{array}{c}100,000 \\
\text { parasitized } \\
\text { eggs }\end{array}$ & $\begin{array}{c}10.93 \\
(19.29)\end{array}$ & $\begin{array}{c}7.36 \\
(15.73)\end{array}$ & $\begin{array}{c}6.56 \\
(14.83)\end{array}$ & $\begin{array}{c}12.03 \\
(20.28)\end{array}$ & $\begin{array}{c}8.23 \\
(16.66)\end{array}$ & $\begin{array}{c}7.86 \\
(16.13)\end{array}$ \\
\hline $\mathrm{T}_{3}$ & 200 & $\begin{array}{c}10.03 \\
(18.45)\end{array}$ & $\begin{array}{c}6.03 \\
(14.21)\end{array}$ & $\begin{array}{c}4.63 \\
(12.41)\end{array}$ & $\begin{array}{c}14.0 \\
(21.96)\end{array}$ & $\begin{array}{c}5.60 \\
(13.66)\end{array}$ & $\begin{array}{c}5.36 \\
(13.38)\end{array}$ \\
\hline $\mathrm{T}_{4}$ & 250 & $\begin{array}{c}11.33 \\
(19.66)\end{array}$ & $\begin{array}{c}6.13 \\
(14.33)\end{array}$ & $\begin{array}{c}4.43 \\
(12.14)\end{array}$ & $\begin{array}{l}13.53 \\
(21.57)\end{array}$ & $\begin{array}{c}6.0 \\
(14.17)\end{array}$ & $\begin{array}{c}6.93 \\
(15.20)\end{array}$ \\
\hline $\mathrm{T}_{5}$ & - & $\begin{array}{c}10.76 \\
(19.14)\end{array}$ & $\begin{array}{c}18.33 \\
(25.34)\end{array}$ & $\begin{array}{c}21.86 \\
(27.86)\end{array}$ & $\begin{array}{l}13.93 \\
(21.90)\end{array}$ & $\begin{array}{c}19.83 \\
(26.43)\end{array}$ & $\begin{array}{c}23.56 \\
(29.02)\end{array}$ \\
\hline $\mathrm{CD}(\mathrm{p}=0.05)$ & & NS & 0.53 & 1.20 & NS & 0.70 & 1.46 \\
\hline
\end{tabular}

Figures in parentheses are arc sine transformed values; level of significance $\mathrm{p}=0.05, \mathrm{~T}_{1}$ : Coragen $18.5 \mathrm{SC}$ (Chlorantriniliptole) @ $75 \mathrm{ml} / \mathrm{ha} ; \mathrm{T}_{2}$ : Tricho cards @ 100,000 parasitized eggs of Corcyra cephalonica, $\mathrm{T}_{3}$ : Decis $2.8 \mathrm{EC}$ (Deltamethrin) @ 200 ml/ ha as standard check, $\mathrm{T}_{4}$ : Farmers Practice (Choloropyriphos 50\% + Cypermethrin 5\%) @ $250 \mathrm{ml} / \mathrm{ha}$; $\mathrm{T}_{5}$ : Control

Table 2. Effect of different treatments on reduction of Dead hearts incidence of C. partellus in maize during Kharif 2012 and 2013.

\begin{tabular}{|c|c|c|c|c|c|c|c|}
\hline \multirow[b]{2}{*}{ Treatments } & \multirow[b]{2}{*}{$\begin{array}{c}\text { Dose } \\
\text { (ml/ha) }\end{array}$} & \multicolumn{3}{|c|}{$\begin{array}{l}\text { Per cent dead heart incidence } \\
\text { (2012) }\end{array}$} & \multicolumn{3}{|c|}{$\begin{array}{l}\text { Per cent dead heart incidence } \\
\text { (2013) }\end{array}$} \\
\hline & & $\begin{array}{l}\text { Before } \\
\text { Spray }\end{array}$ & $\begin{array}{c}\text { days } \\
\text { after } \\
\text { spray }\end{array}$ & $\begin{array}{l}14 \text { days } \\
\text { after } \\
\text { spray }\end{array}$ & $\begin{array}{l}\text { Before } \\
\text { Spray }\end{array}$ & $\begin{array}{c}7 \text { days } \\
\text { after } \\
\text { spray }\end{array}$ & $\begin{array}{c}14 \text { days } \\
\text { after spray }\end{array}$ \\
\hline $\mathrm{T}_{1}$ & 75 & $\begin{array}{c}4.26 \\
(11.89)\end{array}$ & $\begin{array}{c}3.76 \\
(11.16)\end{array}$ & $\begin{array}{c}3.16 \\
(10.23)\end{array}$ & $\begin{array}{c}5.56 \\
(13.74)\end{array}$ & $\begin{array}{c}3.63 \\
(11.90)\end{array}$ & $\begin{array}{c}3.90 \\
(11.36)\end{array}$ \\
\hline $\mathrm{T}_{2}$ & $\begin{array}{l}100,000 \text { parasi- } \\
\text { tized eggs }\end{array}$ & $\begin{array}{c}3.83 \\
(11.26)\end{array}$ & $\begin{array}{c}5.56 \\
(13.18)\end{array}$ & $\begin{array}{c}5.14 \\
(13.11)\end{array}$ & $\begin{array}{c}5.56 \\
(13.62)\end{array}$ & $\begin{array}{c}5.10 \\
(13.40)\end{array}$ & $\begin{array}{c}4.90 \\
(12.75)\end{array}$ \\
\hline $\mathrm{T}_{3}$ & 200 & $\begin{array}{c}5.03 \\
(12.91)\end{array}$ & $\begin{array}{c}4.20 \\
(11.78)\end{array}$ & $\begin{array}{c}3.33 \\
(10.49)\end{array}$ & $\begin{array}{c}5.50 \\
(13.55)\end{array}$ & $\begin{array}{c}4.23 \\
(11.83)\end{array}$ & $\begin{array}{c}3.96 \\
(11.47)\end{array}$ \\
\hline $\mathrm{T}_{4}$ & 250 & $\begin{array}{c}4.46 \\
(12.19)\end{array}$ & $\begin{array}{c}4.60 \\
(12.35)\end{array}$ & $\begin{array}{c}3.53 \\
(10.79)\end{array}$ & $\begin{array}{c}5.60 \\
(13.68)\end{array}$ & $\begin{array}{c}4.73 \\
(12.52)\end{array}$ & $\begin{array}{c}3.96 \\
(11.48)\end{array}$ \\
\hline $\mathrm{T}_{5}$ & - & $\begin{array}{c}4.50 \\
(12.23)\end{array}$ & $\begin{array}{c}7.90 \\
(16.29)\end{array}$ & $\begin{array}{c}14.16 \\
(22.34)\end{array}$ & $\begin{array}{l}13.90 \\
(26.10)\end{array}$ & $\begin{array}{c}10.96 \\
(19.31)\end{array}$ & $\begin{array}{c}18.53 \\
(25.48)\end{array}$ \\
\hline $\mathrm{CD}(\mathrm{p}=0.05)$ & & NS & 1.99 & 1.35 & NS & 1.15 & 0.90 \\
\hline
\end{tabular}

Figures in parentheses are arc sine transformed values; Level of significance $\mathrm{p}=0.05$

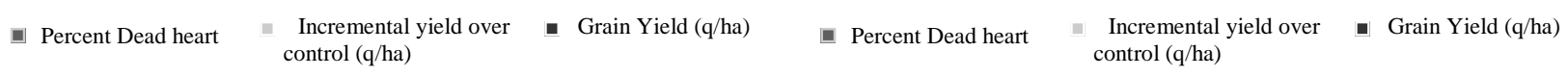

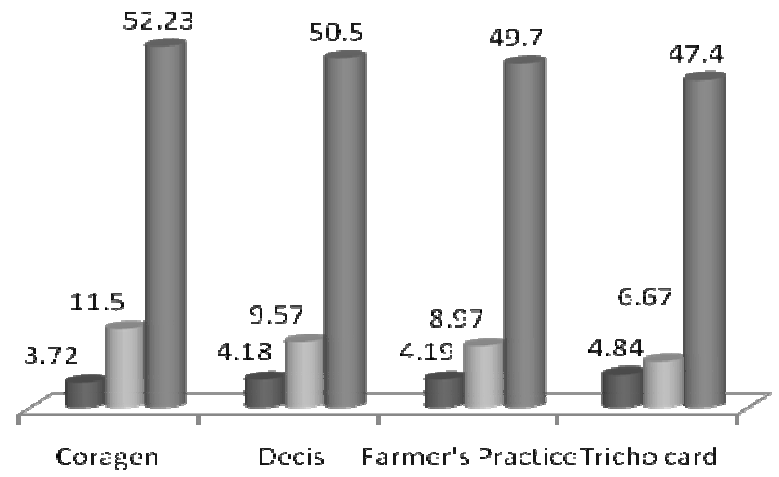

Fig. 1. Effect of different treatments on dead hearts reduction and incremental grain yield of maize during 2012.

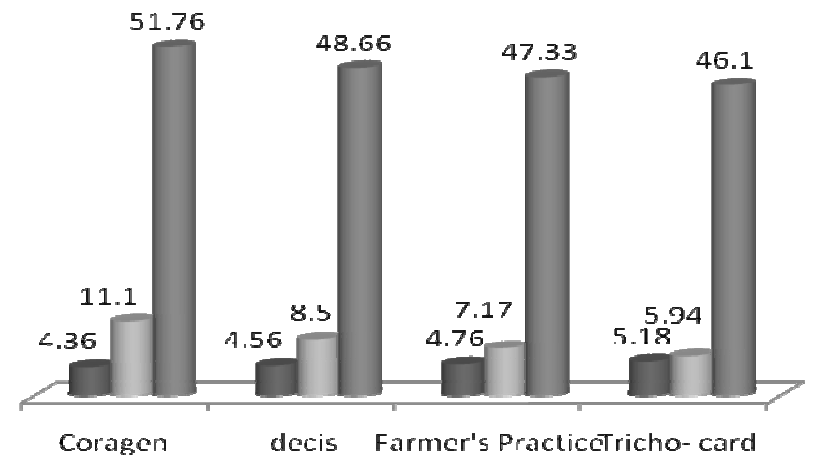

Fig. 2. Effect of different treatments on dead hearts reduction and incremental grain yield of maize during 2013. 
25-30 days old crop offers less benefit due to advanced damaging condition of pest inside whorls thus affecting the efficacy of insecticides and reduction in grain yield.

\section{Conclusion}

The overall superiority of Chlorantrinilprole 18.5 SC in comparison to other conventional insecticide treatments has marked effect on reduction of pest damage in the form of leaf injury level and dead heart incidence. Thus, resulting in higher grain yield and economic returns. Moreover being biorational, it seems environmentally sound approach and offers additional choice of insecticide for farmers to manage the $C$. partellus infestation in maize production system. The treatment involving release of biocontrol agent though helped to reduce the pest load on crop but level of reduction in pest damage and realization of grain yield could not be compared with chlorantriniliprole 18.5 SC treatment. The standard check consisting of old generation synthetic pyrethroid formulation (deltamethrin 2.8 EC) proved in comparison with promising treatment in terms of damage reduction. However there is need to replace old generation chemicals with safer and new chemistry molecules with a distinct class and unique mode of action for sustainable maize production programme.

\section{ACKNOWLEDGEMENTS}

The authors acknowledges the Zonal Project Directorate (ICAR) Ludhiana, Directorate of Extension Education, Punjab Agricultural University, Ludhiana, and Biological Control Unit, Department of Entomology, PAU for providing necessary financial support and other technical inputs during the course of investigation.

\section{REFERENCES}

Aggarwal, N. and Jindal, J. (2013). Validation of Biocontrol technology for suppression of Chilo partellus (Swinhoe) on Kharif maize in Punjab. J. of Biological. Cont. 27 (4) : 278-284.

Anonymous (2013). Annual Report-All India Co-ordinated Maize Improvement Project. Directorate of Maize Research, New Delhi, pp 748.

Anuradha, M. (2013). Evaluation of chlorantraniliprole (Corage $20 \mathrm{SC}$ ) against maize stem borers. Int. J. Plant Prot. 6(1) : 155-158.

Farid, A., Khan, M.I.N., Khan, A., Khattak, S., Alamzeb, U.K. and Sattar, A. (2007). Study of maize stem borer Chilo partellus (Swin.) in Peshawar valley. Pak. J. Zool. 9: 127-131.

Gomez, K.A. and Gomez, A.A. (1984). Statistical Procedures for Agricultural Research. $2^{\text {nd }}$ edition. Wiley -Interscience, New York.

Hannig, G.T., Ziegler, M. and Marçon, P.G. (2009). Feeding cessation effects of chlorantraniliprole, a new anthranilic diamide insecticide, in comparison with several insecticides in distinct chemical classes and mode-of-action groups. Pest Management Science 65: 969-974.

Jalali, S.K., Singh, S.P. (2003). Determination of release rates of natural enemies for evolving bio-intensive management of Chilo partellus (Swinhoe) (Lepidoptera: 
Pyralidae). Shashpa 10: 151-154.

Kumar, S., Kumar, P., Bana, J.K., Shekhar, M., Sushil, S.N., Sinha, M., Sinha, A.K., Asre, R., Kapoor, K.S., Sharma, O.P., Bhagat, S., Sehgal, M., Boopathi, T., Amaresan, N., Chattopadhaya, C., Satyagopal, K. and Jeyakumar, P. (2014). Integrated Pest Management Package for Maize. National Centre for Integrated Pest Management, New Delhi. pp.44.

Marchesini, E., Mori, N., Pasini, M. and Bassi, A. (2008). Selectivity of Rynaxpyr towards beneficial arthropods in different Agrosystems. Giornate- Fitopatologiche, Cervia, Italy. pp71-76.

Rajaval, D.S., Mohanraj and Bharathi, K. (2011). Efficacy of chlorantraniliprole (Coragen 20SC) against brinjal shoot and fruit borer, Leucinodes orbonalis (Guen.). Pest Management in Hort. Ecosystems 17: 28-31.

Singh, G., Prasad, C.S., Sirohi, A., Kumar, A. and Ali, N. (2009). Field evaluation of Rynaxypyr 20 SC against insect pests of sugarcane. Annals of Plant Protection Science. 17: 50-52.

Suri, K.S. (2011). Bioefficacy of some insecticides against rice stem borers and leaf folder infesting rice in Punjab. Pesticide Res. J. 23: 190-193.

Wu-Jun, Z., Hui, Z., Wei, Z., Chao-Bin, W., Guo, N. and Yong-Yang, Z. (2009). Control effect of chlorantraniliprole 18.5 SC against Chilo suppressalis Walker. Chinese Electronic Periodical Services 48: 230-232. 